\title{
Malongitubus: a possible pterobranch hemichordate from the early Cambrian of South China
}

\author{
Shixue Hu, ${ }^{1}$ Bernd-D. Erdtmann, ${ }^{2}$ Michael Steiner, ${ }^{3}$ Yuandong Zhang, ${ }^{4}$ Fangchen Zhao, ${ }^{4}$ Zhiliang Zhang, \\ and Jian $\operatorname{Han}^{5}$ \\ ${ }^{1}$ Chengdu Center, China Geological Survey, Chengdu, 610081, P.R. China 〈hushixue@ 126.com〉 \\ ${ }^{2}$ Institut für Angewandte Geowissenschaften, Technische Universität Berlin, D-13355 Berlin, Germany 〈berni1739@gmail.com〉 \\ ${ }^{3}$ Institut für Geowissenschaften, Freie Universität Berlin, D 12249, Berlin, Germany 〈michael.steiner@FU-Berlin.de〉 \\ ${ }^{4}$ CAS Key Laboratory of Economic Stratigraphy and Palaeogeography, Nanjing Institute of Geology and Palaeontology, 39 East Beijing Road, \\ Nanjing 210008, China 〈ydzhang@nigpas.ac.cn〉,〈fczhao@nigpas.ac.cn〉 \\ ${ }^{5}$ Early Life Institute, State Key Laboratory of Continental Dynamics, Northwest University, Xi'an 710069, China 〈zhangtensor@hotmail.com〉, \\ 〈elihanj@nwu.edu.cn〉
}

\begin{abstract}
Malongitubus kuangshanensis $\mathrm{Hu}, 2005$ from the early Cambrian Chengjiang Lagerstätte of China is redescribed as a pterobranch and provides the best evidence to demonstrate that hemichordates were present as early as Cambrian Stage 3. Interpretation of this taxon as a hemichordate is based on the morphology of the branched colony and the presence of resistant inner threads consistent with the remains of an internal stolon system. The presence of fusellar rings in the colonial tubes cannot be unambiguously proven for Malongitubus, probably due to early decay and later diagenetic replacement of the thin organic material of the tubarium, although weak annulations are still discernible in parts of the tubes. The description of $M$. kuangshanensis is revised according to new observations of previously reported specimens and recently collected additional new material. Malongitubus appears similar in most features to Dalyia racemata Walcott, 1919 from the Cambrian Stage 5 Burgess Shale, but can be distinguished by the existence of disc-like thickenings at the bases of tubarium branching points in the latter species. Both species occur in rare mass-occurrence layers with preserved fragmentary individuals of different decay stages, with stolon remains preserved as the most durable structures. Benthic pterobranchs may have occurred in some early Cambrian shallow marine communities in dense accumulations and provided firm substrates and shelter for other benthic metazoans as secondary tierers.
\end{abstract}

\section{Introduction}

The Pterobranchia are a group of colonial or pseudocolonial hemichordates with a long evolutionary history ranging from the Cambrian to the present day. Extant pterobranchs are benthic and classified into two major orders: the Cephalodiscida and the Rhabdopleurida. A close relationship between rhabdopleurid pterobranchs and graptolites was suggested by some previous studies (Urbanek, 1986, 1994; Urbanek and Dilly, 2000; Mierzejewski and Kulicki, 2003) and confirmed by a cladistic investigation (Mitchell et al., 2013), which indicated that the extinct Graptolithina should be included in the Pterobranchia. On the basis of scanning electron microscope back-scatter electron (SEM-BSE) analyses (Maletz et al., 2005), some fossils previously presumed to represent Cambrian algae have been reinterpreted as pterobranchs (Maletz et al., 2005; Maletz, 2014; LoDuca et al., 2015a, 2015b; Maletz and Steiner, 2015), greatly improving our knowledge of the early fossil record of the Pterobranchia. However, the age of the oldest pterobranchs and even of the Hemichordata is still not settled. The earliest potential candidate for hemichordate fossils so far known is acid-isolated organic fragments of Sokoloviina costata
Kirjanov, 1968 representing tubaria with zigzag-shaped fusellar collars from the basal Cambrian Rovno Formation of Ukraine (Sokolov, 1997, pl. 8.4). Other remains have been reported from Cambrian Stage 5 (Series 3), including the potential colonial pterobranch Yuknessia simplex Walcott, 1919 (LoDuca et al., 2015a) and the tubicolous enteropneust hemichordates Spartobranchus tenuis Caron, Conway Morris, and Cameron, 2013 and Oesia disjuncta Walcott, 1911 (Caron et al., 2013; Nanglu et al., 2016) from the Burgess Shale, and undescribed fragments from the Kaili Formation in Southwest China (Harvey et al., 2012). Frond-like fossil remains with a pair of tentacles from the Chengjiang Lagerstätte were described as Galeaplumosus abilus Hou et al., 2011 and interpreted as a possible hemichordate zooid (Hou et al., 2011). The assignment of the sole known specimen to the hemichordates, however, was questioned by recent studies (LoDuca et al., 2015a; Maletz and Steiner, 2015; Ou et al., 2017). Another potential rhabdopleurid pterobranch from the Niutitang Formation of China (Cambrian Stage 2; Zhao et al., 1999) requires further study, and its pterobranch affinity remains uncertain (Maletz, 2014; LoDuca et al., 2015a; Maletz and Steiner, 2015). The earliest widely accepted occurrences of pterobranchs are from the basal part of 
Stage 5 of the Cambrian Period (Maletz, 2014; LoDuca et al., 2015a; Maletz and Steiner, 2015). In this study, we reinterpret Malongitubus kuangshanensis $\mathrm{Hu}, 2005$ from the early Cambrian Chengjiang Konservat-Lagerstätte (Series 2, Stage 3) as a possible pterobranch, judging mostly from the identification of a resistant internal stolon system.

\section{Geological setting, materials, and methods}

All material is from a single bedding plane in a small quarry on the northwest slope of a hillside near Kuangshan village, $\sim 10 \mathrm{~km}$ southwest of the county town Malong, $100 \mathrm{~km}$ east of Kunming in Yunnan Province, China $\left(25^{\circ} 20^{\prime} 15^{\prime \prime N}\right.$, $103^{\circ} 30^{\prime} 20^{\prime \prime E}$ ). Stratigraphically, this interval belongs to the upper part of the Eoredlichia-Wutingaspis Zone within the Yu' anshan Formation and is equivalent to the strata containing the renowned Chengjiang Biota in Chengjiang County and the Haikou district of Kunming (Luo et al., 1994; Zhang et al., 2001). Associated fossils from the same interval include arthropods (trilobites, bradoriids, and other arthropods), sponges, cnidarians, anomalocaridids, lobopodians, priapulids, hyolithids, brachiopods, chancelloriids, vetulicolians, and algae (a detailed list of fossils is available in the appendices of $\mathrm{Hu}$, 2005 and Zhao et al., 2012), representing a local assemblage of the Chengjiang biota. The lithology of the section and the occurrence of the pterobranch-bearing layer were illustrated previously (Hu, 2005, text-fig. 9; Wang et al., 2012, fig. 1B). The preservation of the probable pterobranchs and other associated fossils was interpreted to be the result of rapid burial by a distal storm event (Hu, 2005; Zhao et al., 2012).

The specimens of Malongitubus kuangshanensis are compressed, often fragmentary, and commonly partly superimposed on one another on the bedding surface. In most cases, the tubes are whitish or pale in color due to intense weathering, with occasional dark remains of original organic material. The materials were prepared using a sharp blade under a binocular microscope. Overall images of the specimens were obtained with a Canon Mark II Camera with an EF $100 \mathrm{~mm}$ f/2.8L IS USM close-up lens under direct light. Enlargements of details at the millimeter scale were photographed with a Zeiss Smartzoom 5 microscope system under fiber-optic lights. BSE pictures were obtained using a HITACHI SU3500 in the Nanjing Institute of Geology and Palaeontology, Chinese Academy of Sciences, China, with an accelerating voltage of 20-30 kV. SEM microphotographs were obtained and energydispersive spectroscopic analysis was conducted at the State Key Laboratory of Continental Dynamics, Northwest University, Xi'an, China, with a ZEISS-SUPRA 40VP.

Repositories and institutional abbreviations.-Nanjing Institute of Geology and Palaeontology, Chinese Academy of Sciences, China (NIGP); Early Life Institute of Northwestern University (ELI). A specimen of Dalyia racemata from the Burgess Shale was also examined in this study (specimen number USNM 194121, Smithsonian Institution, Washington DC, USA). The nomenclature applied in this study follows that of recent works on pterobranchs (Maletz et al., 2005; LoDuca and Kramer, 2014; Maletz, 2014; LoDuca et al., 2015a; Maletz and Steiner, 2015).

\section{Systematic paleontology}

? Phylum Hemichordata Bateson, 1885

? Class Pterobranchia Lankester, 1877

? Subclass Graptolithina Bronn, 1849, emend. Mitchell et al., 2013 Genus Malongitubus Hu, 2005

Type species.—Malongitubus kuangshanensis $\mathrm{Hu}, 2005$.

Diagnosis (emended).-Colonial organism with long, slender, and branching thecal tubes. Thecal tubes parallel-sided, each with an internal continuous thread. There are usually four, or less commonly five, terminal thecal tubes, which are free and in similar widths and lengths. Fine annulations present on the surface of thecal tubes. Terminal thecal tubes narrow distally, commonly with thickened apertures.

Remarks.-Malongitubus closely resembles Dalyia Walcott, 1919 from the Burgess Shale (Cambrian Series 3, Stage 5) in overall colony shape and in having nearly parallel-sided thecal tubes and inner threads of relatively constant dimensions, herein interpreted as a stolon system. The close similarity between the two taxa led to the suggestion of possible synonymy (Maletz and Steiner, 2015). However, Malongitubus differs in having a greatly variable branching distance, from millimeters to centimeters. In addition, the presence of round structures at the branching points of Dalyia (Maletz and Steiner, 2015) allows differentiation of the two taxa. On the basis of this difference, Malongitubus is retained as a separate taxon. Holdfast structures and initial (larval) development of both taxa are unknown. The development of fuselli cannot be proven, but is likely. No zooid remains have been preserved. Comparing to Yuknessia from the Cambrian of British Columbia and Utah, the thecal tubes of Malongitubus are completely free and parallel-sided or slightly expanding, whereas those of Yuknessia conspicuously widen distally. In addition, the presence of repent and erect thecae in Yuknessia also distinguish it from Malongitubus. The absence of more differentiated thecal types, such as autothecae, bithecae, and stolothecae, in M. kuangshanensis indicates that it differs from dendroid graptolites, which have been reported from the traditional "middle Cambrian" and younger strata (Rickards et al., 1990; Johnston et al., 2009; LoDuca and Kramer, 2014).

Malongitubus kuangshanensis $\mathrm{Hu}, 2005$

Figures 1, 2

2005 Malongitubus kuangshanensis Hu, p. 187, pl. 18, figs. 1-7.

2012 Malongitubus kuangshanensis; Wang et al., p. 62, fig. 2A-G.

Holotype.-NIGP-165028 (labeled as Kuangshan-01 in Hu, 2005), a large, nearly complete (base missing) multibranched tubarium with four terminal thecal tubes (Fig. 2.1).

Occurrence.-Kuangshan village, Malong County, Yunnan Province, China. Upper part of the Eoredlichia-Wutingaspis Zone, Yu'anshan Formation, Cambrian Stage 3, Series 2, early Cambrian. 

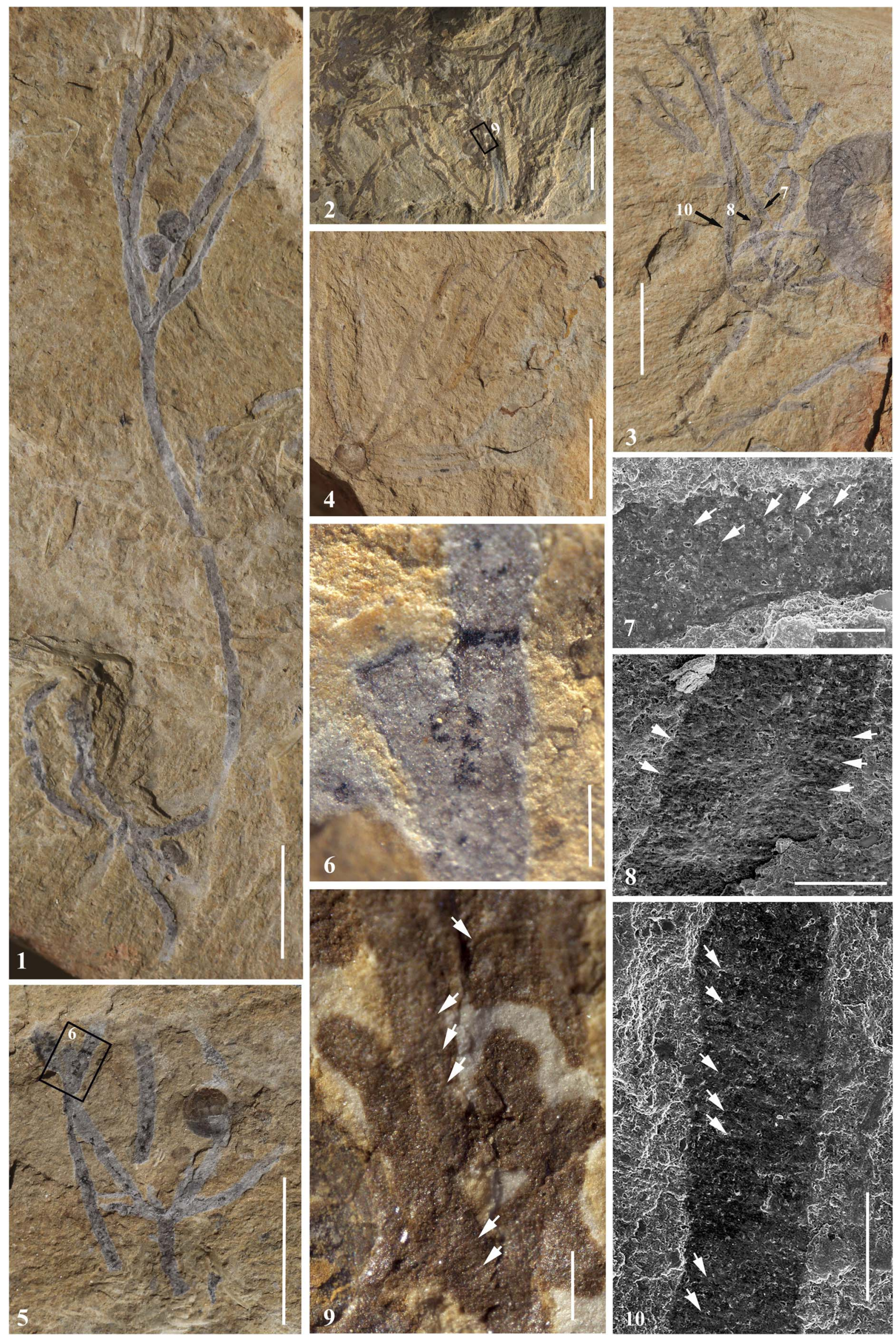

Downloaded from https://www.cambridge.org/core. TU Berlin Universitaetsbibliothek, on 04 Jul 2019 at 14:13:27, subject to the Cambridge Core terms of use, available at 
Description.-Maximum height of the tubarium is $6 \mathrm{~cm}$. Tubarium branches are 0.4 to $0.5 \mathrm{~mm}$ wide. Distances between bifurcations vary from $1 \mathrm{~mm}$ to several centimeters. Remains of soft-bodied zooids are not evident. Thecal tubes mostly straight or curved, sometimes bent (Fig. 1.1). The angle of the thecal tubes to the stipe varies from 15 to 70 degrees. The width of the terminal thecal tubes varies from $250 \mu \mathrm{m}$ at the aperture to $400 \mu \mathrm{m}$ at the location just above the branching point. The number of terminal thecal tubes is usually four, or less commonly five (Hu, 2005, pl. 18, figs. 4, 5). The terminal thecal tubes are free with similar widths and lengths. The apertures of the thecal tubes appear to narrow slightly and are thickened (Fig. 1.6; Hu, 2005, pl. 18, fig. 5). Energy-dispersive spectroscopic analysis reveals that the dark remains on the tubes are organic carbon (Fig. 2.9-2.15).

A number of remains of tubaria show a darker internal thread of relatively constant width, herein interpreted as remains of an original stolon system (Figs. 1.5, 2.3, 2.6). As a result of weathering and early decay, the stolon system is preserved as fragments (Figs. 1.5, 2.4), with only a few cases in which the stolon is visible as a continuous thread for a distance of more than a few millimeters (Fig. 2.6). The stolon is divided where the tubarium branches. The width of the stolon is about $10 \mu \mathrm{m}$. Transverse annulations of the tubaria are sometimes faintly preserved (Fig. 1.7-1.10) and may have resulted from previously existing fusellar structures. The heights of the annulations are about $20 \mu \mathrm{m}$. However, no unequivocal fusellar structures are presently documented.

Due to fragmentary preservation of all available specimens, no basal parts of tubaria are observed; thus, the means of colony attachment to the substrate cannot be determined.

Other material.-About 20 specimens with incomplete parts of the tubarium and a large number of incomplete thecal tubes or branches.

Remarks.-When the taxon Malongitubus kuangshanensis was erected, the phylogenetic affinity of the species was kept open, and the similarity with Dalyia racemata from the Burgess Shale was discussed briefly. At that time, the latter was considered to be an alga, but is now recognized as a possible pterobranch hemichordate (Maletz and Steiner, 2015). The possible pterobranch affinity of $M$. kuangshanensis was also mentioned by Maletz and Steiner (2015) but not discussed in detail. The identification of a resistant stolon system indicates that it has a close affinity to the Pterobranchia and more generally that it is a colonial organism. A "stolon" has sometimes been reported from extant hydrozoan colonies, which are morphologically and functionally differentiated into hydrorhiza, hydrocaulus, and especially swollen hydrotheca (Brusca and Brusca, 2003; Ruppert et al., 2004). However, in colonial hydrozoans, the "stolon" represents a thin extension of the hydropolyp, which is not sclerotized as in pterobranchs and is thus differentiated as coenosarc. While the chitinous perisarc and hydrothecae of colonial hydrozoans may have some fossilization potential, it is rather unlikely that the coenosarc would be preserved in the fossil record. By contrast, decay experiments on modern pterobranchs have demonstrated that the sclerotized stolon system is one of the most durable structures of pterobranch colonies and may prevail until most of the zooids and tubarium have decayed (Beli et al., 2017). In Malongitubus, and notably also in the closely related Dalyia racemata from the Cambrian Stage 5 Burgess Shale, the putative stolon system is the most resistant structure of the fossil remains. This is also shown by the fact that sometimes only stolons remain after decay or parts of stolons extend out of decayed tubaria (Fig. 3). Dalyia was originally interpreted as a red alga (Walcott, 1919), but was recently reinterpreted as a colonial graptolite by Maletz and Steiner (2015) from the identification of a possible stolon system. Therefore, M. kuangshanensis is also interpreted as a probable pterobranch due to the existence of a sclerotized stolon system. Its placement within the Cephalodiscida can be excluded, since the latter are noncolonial and lack a stolon system. Further assignment within the Graptolithina is not attempted herein.

Attempts at identifying fusellar structures by SEM-BSE were unsuccessful in the current study. This is probably due to the loss of most of the original organic material of the tube wall as a result of early decay and weathering, leaving only weak imprints of annulations, which are likely to be difficult to detect. The loss of organic material in the main part of the tubarium is also confirmed by the energy-dispersive spectroscopic analysis (Fig. 2.9-2.15). This interpretation also can be applied to Dalyia racemata from the Burgess Shale. As indicated by Maletz and Steiner (2015), all available specimens of D. racemata are diagenetically altered and pale in color, and no original organic material is present.

Taphonomic experiments on modern pterobranchs (Briggs et al., 1995; Beli et al., 2017) show different rates of decay between zooids, tubaria, and the stolon system. The zooids decay rapidly and become unrecognizable after a few days, whereas the tubes and the interior stolon system can last for several months. This decay process of modern pterobranchs can be applied to M. kuangshanensis, which shows well-preserved tube outlines and stolon system and the absence of any zooids. Preservation of zooids is extremely rare in the fossil record of pterobranchs. The most substantial record is the putative reports by Durman and Sennikov (1993) and Sennikov (2016) of soft tissue in a middle Cambrian (Drumian) rhabdopleurid from Siberia. Remarkably, a few specimens of arthropods (e.g., Naraoia) from the same bedding plane as $M$. kuangshanensis show well-preserved diverticula (Hu, 2005, pl. 13, fig. 7; Zhao et al., 2012, fig. 7N), indicating favorable conditions for soft-tissue preservation. It seems likely that individuals of M. kuangshanensis were exposed on the seafloor and subjected

Figure 1. Malongitubus kuangshanensis from the upper part of the Yu'anshan Formation. (1) NIGP-165029: a colony with a bent lower portion and a branched upper portion. (2) NIGP-105030: dense tubaria overlapping each other. The framed area is enlarged in (9). (3) NIGP-105031: a branched colony with a priapulid worm, Maotianshania cylindrica, to the right. The areas indicated by the black arrows are enlarged in (7, 8, 10). (4) ELI-B CLP K007A: a radiating colony. Note the brachiopod to the bottom left. (5) ELI- B CLP K010, part: a colony with a branching tubarium and a stolon system. (6) Thecal apertures. Close-up of the area framed in (5). (7, 8) SEM photograph showing the weak imprints of annulations. White arrows indicate the annulations interpreted as traces of possible fusellar construction. (9) Close-up of the area framed in (2), showing annulations of the tubarium. Some of the annulations are indicated by white arrows. (10) SEM photograph showing the weak imprints of annulations. (1-5) Scale bars $=5 \mathrm{~mm} ;(\mathbf{6}, \mathbf{9}, \mathbf{1 0})$ scale bars $=0.5 \mathrm{~mm} ;(\mathbf{7})$ scale bar $=200 \mu \mathrm{m} ;(\mathbf{8}) \mathrm{scale}$ bar $=300 \mu \mathrm{m}$. 

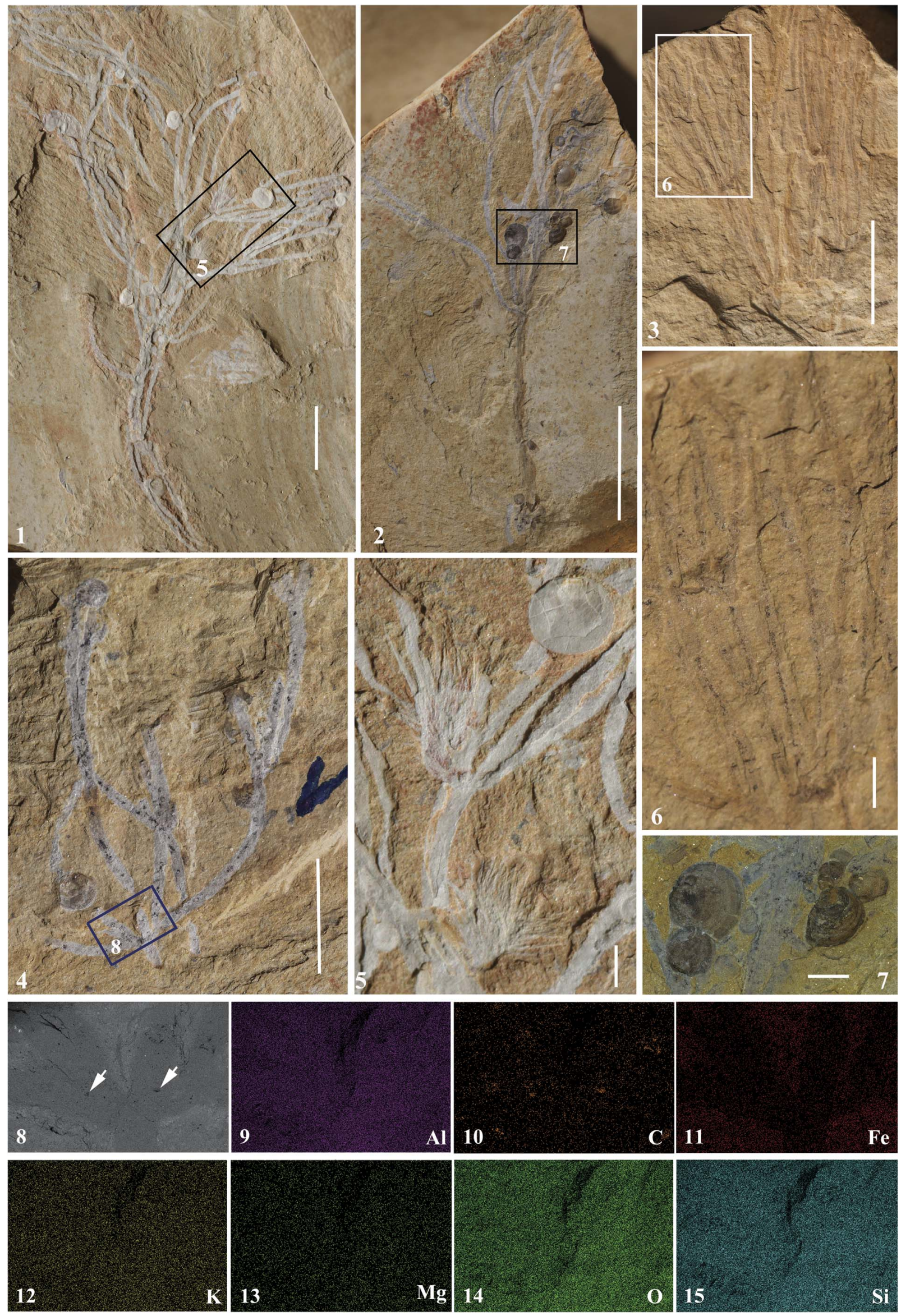

Downloaded from https://www.cambridge.org/core. TU Berlin Universitaetsbibliothek, on 04 Jul 2019 at 14:13:27, subject to the Cambridge Core terms of use, available at https://www.cambridge.org/core/terms. https://doi.org/10.1017/jpa.2017.134 

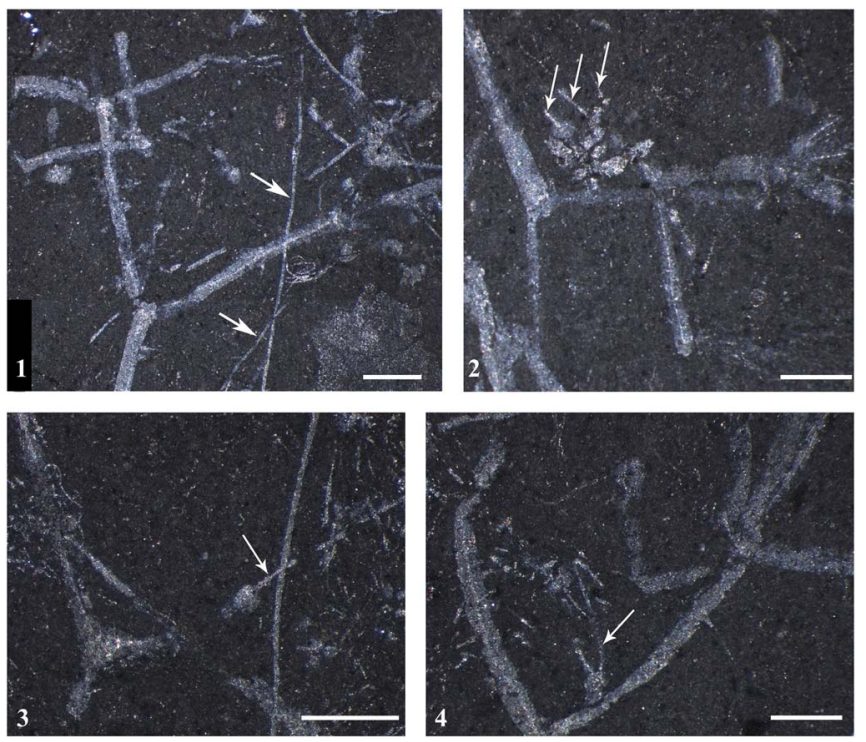

Figure 3. Dalyia racemata from the Cambrian Stage 5 Burgess Shale, No. USNM 194121, Smithsonian Institution. (1) Repeated dichotomous branching of tubarium with distinct threads within the partly decayed tubarium, interpreted as a sclerotized stolon system; thinner filaments besides the branched tubarium represent separated stolons from decayed colonies (arrows) (2) Branched tubarium with internal stolons; separated, decayed branching shows that tube material was decayed and only thickened round basal part of tube and fragments of stolons are left (arrows). (3) Partly decayed tubarium with retained left tube with inner stolon and decayed right tube with exposed stolon (arrow). (4) Branched tubarium with stolon in the left tube; remains of stolons of decayed colonies (arrow). Scale bars $=1.0 \mathrm{~mm}$.

to microbial decay before final burial; consequently, the zooids disappeared due to protracted decay.

\section{Paleoecology}

Tiny brachiopods are observed on some of the specimens (Fig. 2.1, 2.2, 2.4, 2.5, 2.7). The brachiopods range from 0.8 to $2.2 \mathrm{~mm}$ in diameter. The shells of the brachiopods are complete and articulated, with the two valves fitted together. These tiny brachiopods are called Kuangshanotreta malungensis Zhang, Holmer, and $\mathrm{Hu}$ in Wang et al., 2012 and are assigned to the acrotretoids (Wang et al., 2012). All individuals of $K$. malungensis are directly in contact with the tubes and are oriented with the posterior margin toward the tubes (Fig. 2.5, 2.7). Judging from the overall colony arrangement and the attachment of brachiopods, it seems likely that M. kuangshanensis was a benthic, erect pterobranch that was attached to a firm substrate while alive. The attached small brachiopods are interpreted as secondary tierers, which are benthic suspension feeders that use primary tierers to reach higher water levels above the seafloor to obtain a feeding advantage. This interpretation is also supported by the fact that these brachiopods are very rare in the surrounding matrix. Some other brachiopod species have also been interpreted as secondary tierers (Zhang et al., 2010), but they were only able to occupy lower levels (less than $5 \mathrm{~cm}$ above the seafloor; Wang et al., 2012), whereas those on M. kuangshanensis could reach slightly higher elevations. In addition to the miniature brachiopods, five juvenile individuals of the sponge Choia sp. are attached to the tubarium of the holotype of M. kuangshanensis (Fig. 2.1, 2.5). The sponges are 4-5 mm tall (Fig. 2.5), implying probable secondary tiering. Benthic pterobranchs may have occurred in some early Cambrian shallow marine communities in dense accumulations and provided firm substrates and shelter for other benthic metazoans as secondary tierers. Pterobranchs played an important role in early Cambrian marine benthic communities. The interpretation of $M$. kuangshanensis as a pterobranch also indicates that a brachiopod-pterobranch association had likely developed by the Cambrian Series 2, representing an early form of metazoan commensalism.

\section{Acknowledgments}

This work was supported by the National Basic Research Program (2013CB835006); the Strategic Priority Research Program (B) of the Chinese Academy of Sciences (XDB18030304); and the National Natural Science Foundation of China (Grant Nos. 41425008, 41472012). We are grateful to M. Zhu, Nanjing Institute of Geology and Palaeontology, Chinese Academy of Sciences, and Z. Zhang, Northwest University, for constructive discussion and suggestions. The help of J. Thompson, University of Southern California, USA, and L. Muir, Amgueddfa Cymru - National Museum of Wales, UK, in improving the English of the manuscript is gratefully acknowledged. We also thank J. Jin and two reviewers for their most valuable comments and criticisms.

\section{References}

Bateson, W., 1885, The later stages in the development of Balanoglossus kowalevskii, with a suggestion as to the affinities of the Enteropneusta: Quarterly Journal of Microscopical Science, v. 25, p. 81-122.

Beli, E., Piraino, S., and Cameron, C.B., 2017, Fossilization processes of graptolites: Insights from the experimental decay of Rhabdopleura sp. (Pterobranchia): Palaeontology, v. 60, p. 389-400.

Briggs, D.E.G., Kear, A.J., Baas, M., de Leeuw, J.W., and Rigby, S., 1995, Decay and composition of the hemichordate Rhabdopleura: Implications for taphonomy of graptolites: Lethaia, v. 28, p. 15-23.

Bronn, H.G., 1849, Index Palaeontologicus oder Übersicht der bis jetzt bekannten fossilen Organismen, Prof. H. R. Göppert und Herm. V. Meyer, in Bronn H.G. ed., Zweite Abtheilung. B. Enumerator palaeontologicus: Systematische Zusammenstellung und geologische EntwicklungsGesetze der organischen Reiche: Stuttgart, E. Schweizerbart'sche Verlagsbuchhandlung, $976 \mathrm{p}$.

Brusca, R.C., and Brusca, G.J., 2003, Invertebrates: Paris, Sinauer Associates, $922 \mathrm{p}$.

Caron, J.B., Conway Morris, S., and Cameron, C.B., 2013, Tubicolous enteropneusts from the Cambrian period: Nature, v. 495, p. 503-506.

Durman, P.N., and Sennikov, N.V., 1993, A new Rhabdopleurid hemichordate from the middle Cambrian of Siberia: Palaeontology, v. 36, p. 283-296.

\footnotetext{
Figure 2. Malongitubus kuangshanensis and attached brachiopods and sponges as secondary tierers. (1) Holotype, NIGP-165028, showing the associated brachiopods and sponges. (2) NIGP-165032, showing the attachment of numerous brachiopods onto the tubes. (3) NIGP-165033. Densely arranged tubes. Close-up of the area framed in (6). (4) ELI-B CLP K010B, counterpart: a colony with both adult and juvenile brachiopods. (5) Close-up of the area framed in (1), showing two sponges and one brachiopod on the tubes. (6) Close-up of the area framed in (3), showing the dark, continuous stolon. (7) Close-up of the two juvenile brachiopods indicated by the framed area in (2). (8) BSE image of the area marked by the frame in (4). White arrows point to the organic remains. (9-15) Energy-dispersive spectroscopic analysis of the tubarium in (8). (1-3) Scale bars $=10 \mathrm{~mm} ;(\mathbf{4})$ scale bar $=5 \mathrm{~mm} ;(\mathbf{5}, \mathbf{6})$ scale bars $=1 \mathrm{~mm} ;(\mathbf{7}) \mathrm{scale}$ bar $=0.5 \mathrm{~mm}$.
} 
Harvey, T.H.P., Ortega-Hernández, J., Lin, J.-P., Zhao, Y.-L., and Butterfield, N.J., 2012, Burgess Shale-type microfossils from the middle Cambrian Kaili Formation, Guizhou Province, China: Acta Palaeontologica Polonica, v. 57 , p. $423-436$.

Hou, X.-G., Aldridge, R.J., Siveter, D.J., Derek, J., Williams, M., Zalasiewicz, J., and Ma, X.-Y., 2011, An early Cambrian hemichordate zooid: Current Biology, v. 21, p. 612-616.

Hu, S.-X., 2005, Taphonomy and palaeoecology of the early Cambrian Chengjiang Biota from Eastern Yunnan, China: Berliner Paläeobiologische Abhandlungen, v. 7, p. 185-187.

Johnston, K.J., Johnston, P.A., and Powell, W.G., 2009, A new, middle Cambrian, Burgess Shale-type biota, Bolaspidella Zone, Chancellor Basin, southeastern British Columbia: Palaeogeography, Palaeoclimatology, Palaeoecology, v. 277, p. 106-126.

Kirjanov, V.V., 1968, Paleontology and stratigraphy of the Baltic deposits in the Volhyn-Podolia, in Paleontology and Stratigraphy of the Lower Paleozoic of Volhyn-Podolia: Kiev, Naukova Dumka, p. 5-27 [in Russian].

Lankester, E.R., 1877, Notes on the embryology and classification of the animal kingdom: Comprising a revision of speculations relative to the origin and significance of the germ-layers: Quarterly Journal of Microscopical Science, N. S., v. 17 , p. $399-454$.

LoDuca, S.T., and Kramer, A., 2014, Graptolites from the Wheeler and Marjum Formations (Cambrian, Series 3) of Utah: Journal of Paleontology, v. 88, p. 403-410.

LoDuca, S.T., Caron, J.B., Schiffbauer, J.D., Xiao, S.-H., and Kramer, A., 2015a, A reexamination of Yuknessia from the Cambrian of British Columbia and Utah: Journal of Paleontology, v. 89, p. 82-95.

LoDuca, S.T., Wu, M.Y., Zhao, Y.L., Xiao, S.-H., Schiffbauer, J.D., Caron, J.B., and Babcock, L.E., 2015b, Reexamination of Yuknessia from the Cambrian of China and first report of Fuxianospira from North America: Journal of Paleontology, v. 89, p. 899-911.

Luo, H.L., Jiang, Z.W., and Tang, L.D., 1994, Stratotype section for lower Cambrian Stages in China: Kunming, Yunnan Science and Technology Press, 183 p. [in Chinese with English summary].

Maletz, J., 2014, Fossil Hemichordata (Pterobranchia, Enteropneusta): Palaeogeography, Palaeoclimatology, Palaeoecology, v. 398, p. 16-27.

Maletz, J., and Steiner, M., 2015, Graptolite (Hemichordata, Pterobranchia) preservation and identification in the Cambrian Series 3: Palaeontology, v. 58, p. 1073-1107.

Maletz, J., Steiner, M., and Fatka, O., 2005, Middle Cambrian pterobranchs and the Question: What is a graptolite?: Lethaia, v. 38, p. 73-85.

Mierzejewski, P., and Kulicki, C., 2003, Cortical fibrils and secondary deposits in periderm of the hemichordate Rhabdopleura (Graptolithoidea): Acta Palaeontologica Polonica, v. 48, p. 99-111.

Mitchell, C.E., Melchin, M.J., Cameron, C.B., and Maletz, J., 2013, Phylogenetic analysis reveals that Rhabdopleura is an extant graptolite: Lethaia, v. 46, p. $34-56$

Nanglu, K., Caron, J.-B., Conway Morris, S., and Cameron, C.B., 2016, Cambrian suspension-feeding tubicolous hemichordates: BMC Biology, v. 14, p. 56, doi: 10.1186/s12915-016-0271-4.
Ou, Q., Han, J., Zhang, Z.F., Shu, D.G., Sun, G., and Mayer, G., 2017, Three Cambrian fossils assembled into an extinct body plan of cnidarian affinity: Proceedings of the National Academy of Sciences, v. 114 p. $8835-8840$

Rickards, R.B., Baillie, P.W., and Jago, J.B., 1990, An upper Cambrian (Idamean) dendroid assemblage from near Smithton, northwestern Tasmania: Alcheringa, v. 14, p. 207-232.

Ruppert, E.E., Fox, R.S., and Barnes, R.D., 2004, Invertebrate Zoology: A Functional Evolutionary Approach: Belmont, CA, Cole Publishing, 963 p.

Sennikov, N.V., 2016, Morphology of the exoskeleton and soft tissues of Cambrian rhabdopleurids: Paleontological Journal, v. 50, p. 1626-1636.

Sokolov, B.S., 1997, Essays on the advent of the Vendian System: Moscow, KMK Scientific Press Ltd., 156 p.

Urbanek, A., 1986, The enigma of graptolite ancestry: Lesson from a phylogenetic debate, in Hoffman, A., and Nitecki, M.H., eds., Problematic Fossil Taxa: New York, Oxford University Press, p. 184-225.

Urbanek, A., 1994, Living non-graptolite: Lethaia, v. 27, p. 18

Urbanek, A., and Dilly, P.N., 2000, The stolon system in Rhabdopleura compacta (Hemichordata) and its phylogenetic implications: Acta Palaeontologica Polonica, v. 45, p. 201-226.

Walcott, C.D., 1911, Cambrian geology and palaeontology. Middle Cambrian annelids. Smithsonian Miscellaneous: Collections, v. 57, p. 107-144.

Walcott, C.D., 1919, Cambrian geology and palaeontology IV. Middle Cambrian algae: Smithsonian Miscellaneous Collections, v. 67, p. 217-260.

Wang, H.Z., Zhang, Z.F., Holmer, L.E., Hu, S.X., Wang, X.R., and Li, G.X., 2012, Peduncular attached secondary tiering acrotretoid brachiopods from the Chengjiang fauna: Implications for the ecological expansion of brachiopods during the Cambrian explosion: Palaeogeography, Palaeoclimatology, Palaeoecology, v. 323-325, p. 60-67.

Zhang, W.T., Babcock, L.E., Xiang, L.W., Sun, W.G., Luo, H.L., and Jiang, Z.W., 2001, Lower Cambrian stratigraphy of Chengiiang, eastern Yunnan, China with special notes on the Chinese Parabadiella, Moroccan Abadiella and Australian Abadiella huoi: Acta Palaeontologica Sinica, v. 40, p. 294-309 [in Chinese with English summary].

Zhang, Z.F., Han, J., Wang, Y., Emig, C.C., and Shu, D.G., 2010, Epibionts on the lingulate brachiopod Diandongia from the early Cambrian Chengjiang Lagerstätte, South China: Proceedings of Royal Society of London B: Biological Science, v. 277, p. 175-181.

Zhao, F.C., Hu, S.X., Caron, J.B., Zhu, M.Y., Yin, Z.J., and Lu, M., 2012 , Spatial variation in the diversity and composition of the lower Cambrian (Series 2, Stage 3) Chengjiang Biota, Southwest China: Palaeogeography, Palaeoclimatology, Palaeoecology, v. 346-347, p. 54-65.

Zhao, Y.L., Steiner, M., Yang, R.D., Erdtmann, B.-D., Guo, Q.J., Zhou, Z., and Wallis, E., 1999, Discovery and significance of the early metazoan biotas from the lower Cambrian Niutitang Formation, Zunyi, Guizhou, China: Acta Palaeontologica Sinica, v. 38 (Suppl.), p. 132-144 [in Chinese with English summary].

Accepted 17 October 2017 